\title{
ANALISIS FAKTOR PENYEBAB JEBOLNYA TANGGUL SITU GINTUNG
}

\author{
Budi Harsoyo \\ UPT Hujan Buatan, Badan Pengkajian dan Penerapan Teknologi (BPPT). \\ Jalan MH. Thamrin no. 8, Gd.I Lt.19, Jakarta Pusat \\ E-mail : buhar04@yahoo.com
}

\begin{abstract}
Spatial and hidrology analysis has been done to find out the main factor of causing the burst of Situ Gintung dam incident on March 27, 2009. Spatial analysis was done to get some parameters that needs as input for hidrology analysis. The analysis results indicating that rain fall actually was be one of cause factors that incident, but not as the main factor. The condition of dike which already broken as the consequence of its life time and also the condition of spill way which has not function as like as innitialy built by Nederland Goverment, is more as principal factor of causing the burst of Situ Gintung dam incident.
\end{abstract}

Keywords : Situ Gintung, analysis, spatial, hidrology, cause factors.

\section{PENDAHULUAN}

Musibah jebolnya tanggul Situ Gintung di daerah Cireundeu, Tangerang Selatan, Banten pada hari Jumat dini hari tanggal 27 Maret 2009 yang lalu kembali menambah daftar bencana alam yang terjadi di Indonesia dalam beberapa tahun terakhir ini. Lebih dari seratus korban jiwa meninggal dan ratusan korban lainnya mengalami luka - luka dalam musibah ini. Selain itu tercatat sebanyak 260 keluarga kehilangan tempat tinggal akibat air bah bagaikan tsunami yang menghantam daerah permukiman daerah di sekitarnya, yang secara topografi berada di bawah elevasi titik lokasi tanggul yang jebol tersebut (Gambar 1a). Situ yang dibangun oleh pemerintah kolonial Belanda pada tahun 19321933 ini semula didesain untuk keperluan irigasi bagi areal pertanian di sekitarnya, namun perlahan-lahan kini areal tersebut sudah berubah fungsi menjadi lahan permukiman yang cukup padat. Penduduk yang tinggal pada lahan permukiman yang semula adalah lahan pertanian inilah yang menjadi korban dalam bencana tersebut (Gambar 1b, area yang diarsir warna merah muda).

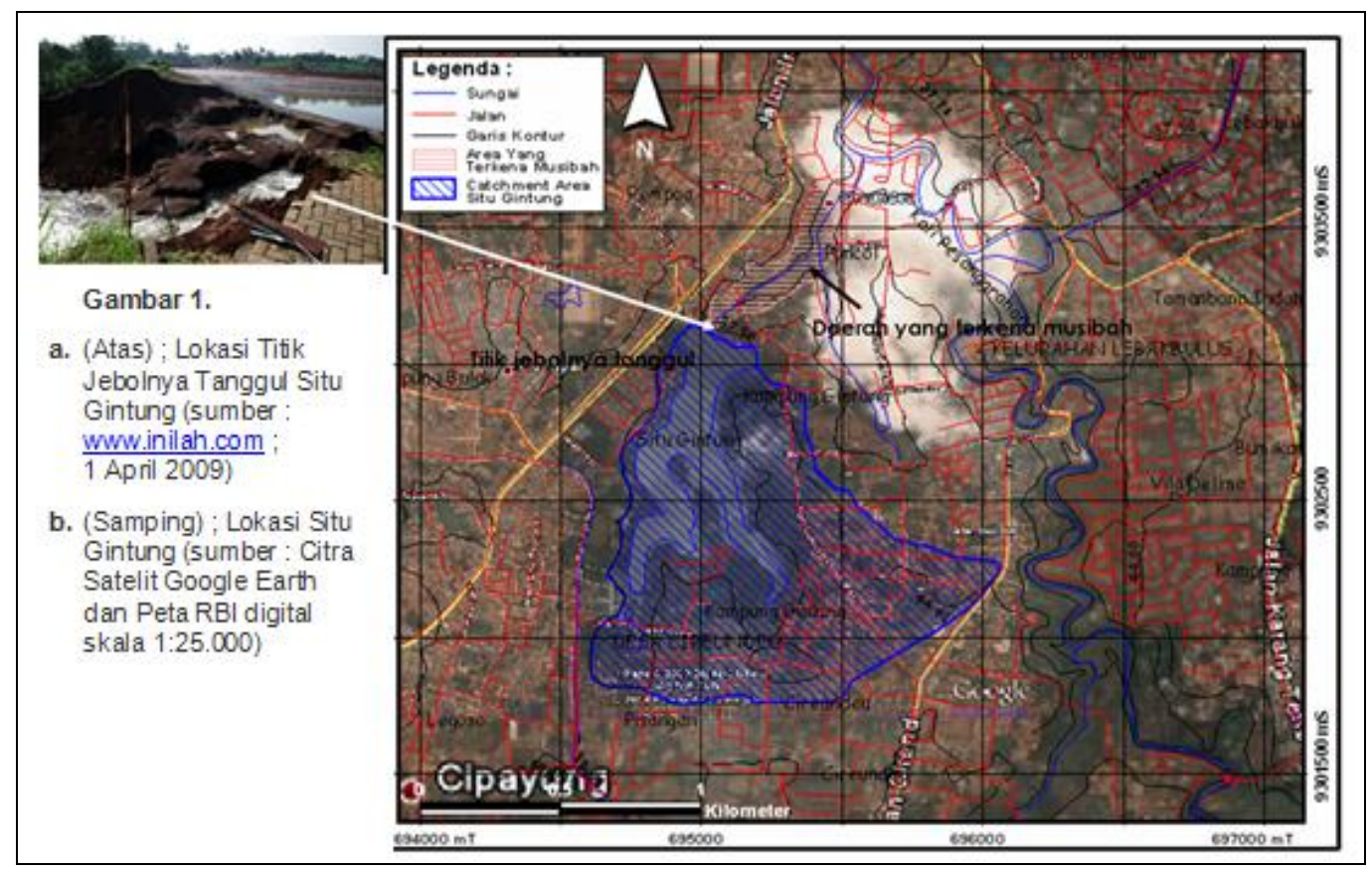

Gambar 1. Gambar dan Peta Lokasi Situ Gintung. 
Sebagian pihak menganggap bahwa musibah jebolnya tanggul situ yang sudah berumur 76 tahun ini disebabkan karena faktor cuaca ekstrim yaitu tingginya intensitas hujan yang terjadi pada malam harinya, sementara pihak lain menilai bahwa musibah ini terjadi akibat faktor usia bangunan tanggul yang memang sudah terlampau tua dan mengalami kerusakan. Penulis pribadi sependapat dengan pendapat yang kedua. Tanpa bermaksud untuk menyudutkan pihak-pihak tertentu, tulisan ini bermaksud untuk membuktikan bahwa musibah jebolnya tanggul Situ Gintung bukan disebabkan oleh curah hujan ekstrim sebagai faktor utamanya, tetapi lebih kepada faktor usia tanggul yang sudah melampaui umur ekonomisnya, dan akhirnya mengalami kerusakan karena tidak lagi sanggup menahan beban air di dalam situ. Penulis menganalisis faktor penyebab terjadinya musibah tersebut melalui pendekatan secara spasial dan hidrologis. Analisis spasial dilakukan untuk mendapatkan beberapa parameter yang diperlukan sebagai masukan dalam melakukan analisis hidrologi. Sebagian data yang digunakan dalam melakukan analisis merupakan data sekunder yang diambil dari beberapa artikel surat kabar ataupun di internet sebagai referensi.

\section{ANALISIS SPASIAL}

\subsection{Kondisi Topografi dan Catchment Area Situ Gintung}

Berdasarkan hasil analisis spasial dengan menggunakan data citra satelit dari Google Earth yang dipadukan dengan Peta Rupa Bumi Indonesia (RBI) dari Bakosurtanal skala 1:25.000 (Gambar 2), terlihat bahwa kondisi topografi di sekitar Situ Gintung relatif datar, sehingga sebenarnya agak sulit untuk membatasi daerah tangkapan air (catchment area)nya. Ditambah dengan tidak adanya aliran sungai yang masuk sebagai inlet bagi reservoir Situ Gintung, batas catchment area didelineasi dengan mengacu pada data Digital Elevation Model (DEM) yang dibangun berdasarkan layer kontur dari Peta RBI digital skala 1:25.000. Kali Pesanggrahan mengalir di sebelah timur Situ Gintung, dan aliran sungainya menyatu dengan aliran dari outlet Situ Gintung di titik lokasi permukiman yang tergenang akibat luapan air dari tanggul yang jebol di Desa Poncol, seperti yang dapat dilihat pada Gambar 2.

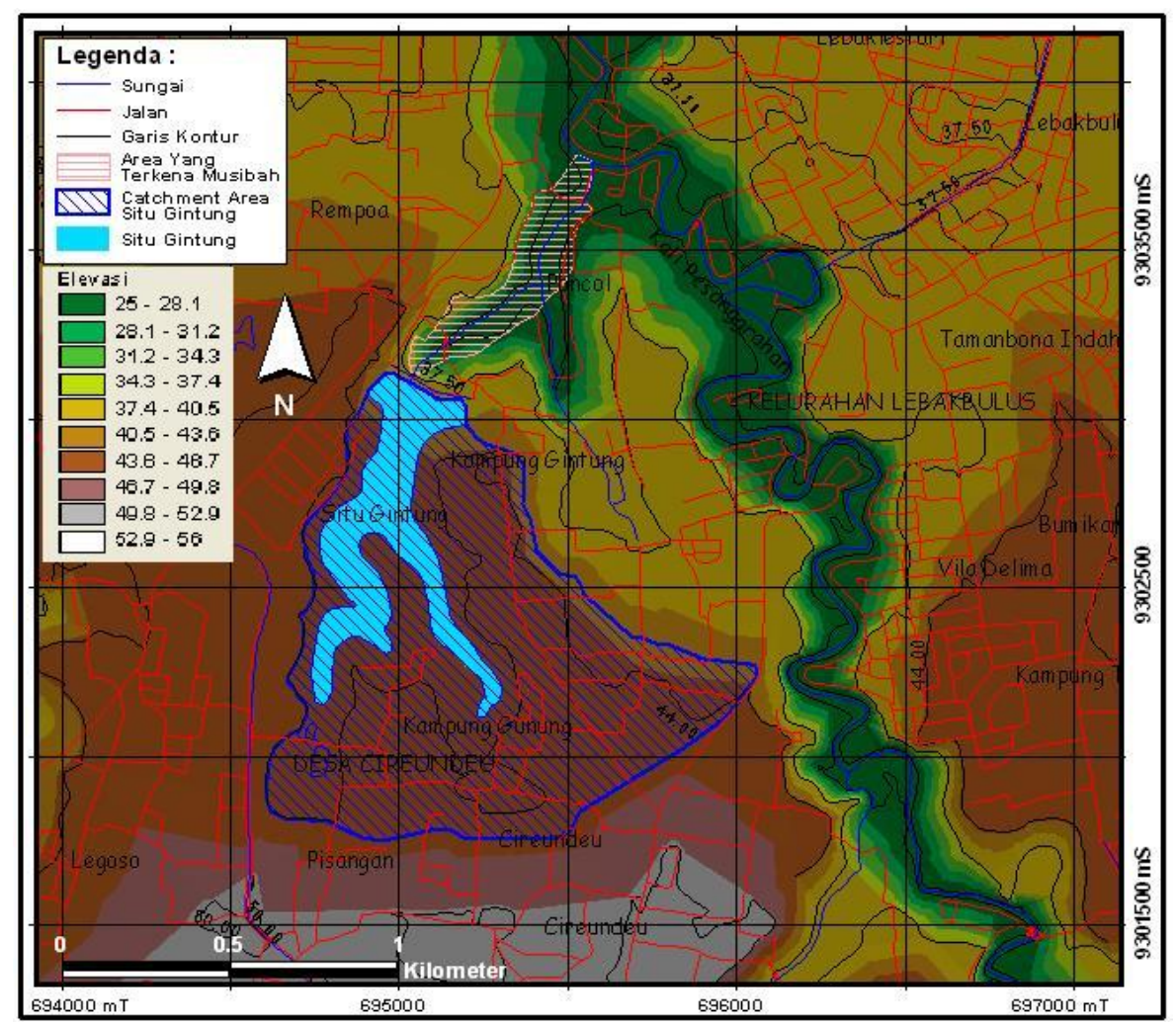

Gambar 2. Digital Elevation Model lokasi Situ Gintung (sumber : Peta RBI digital skala 1:25.000) 
Secara umum berdasarkan data Digital Elevasi Model pada Gambar 2, topografi di sebelah selatan Situ Gintung lebih tinggi dibandingkan dengan daerah sekitarnya, dengan elevasi sekitar 49,8 - 52,9 m. Semakin ke arah utara elevasinya semakin rendah. Wilayah sekitar tanggul yang jebol mempunyai kisaran elevasi sekitar 40,5 - 43,6 m, sedangkan wilayah terkena dampak umumnya merupakan wilayah yang lebih rendah dengan elevasi sekitar 25 $28,1 \mathrm{~m}$. Perbedaan tinggi antara wilayah tanggul dengan wilayah terkena dampak lebih dari $20 \mathrm{~m}$, sehingga dapat dibayangkan bagaimana dahsyatnya terjangan air yang menyapu habis daerah permukiman di bawah tanggul pada saat tanggul jebol. Kenampakan 3 dimensi dari catchment area Situ Gintung digambarkan dalam Gambar 3 berikut ini.

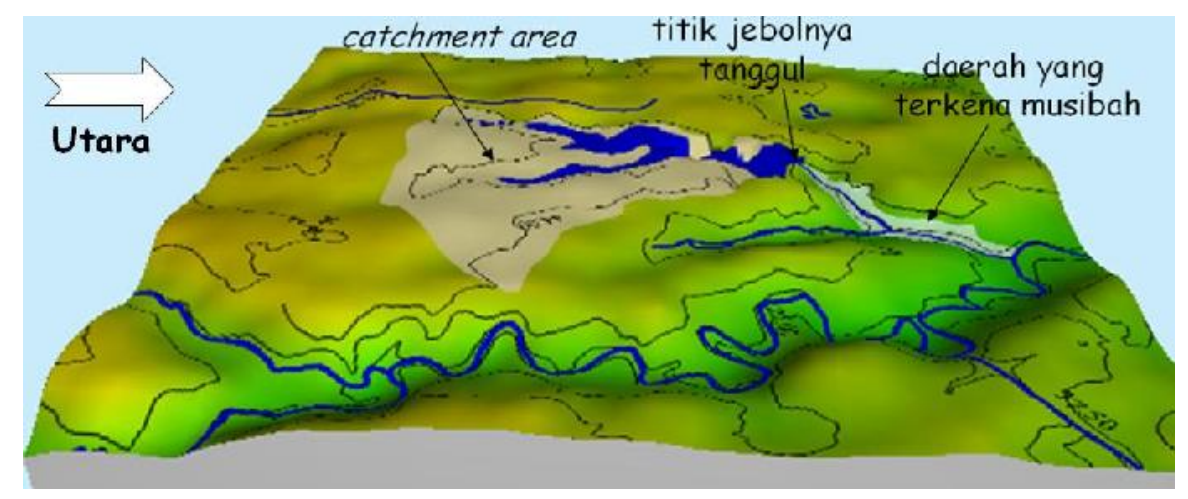

Gambar 3. Kenampakan 3 dimensi catchment area Situ Gintung

Menurut Kepala Bidang Mitigasi Bencana BPPT, Sutopo Purwo Nugroho, Situ Gintung mendapatkan suplai air dari cathment area dan mata air asli di lokasi tersebut(1). Berdasarkan hasil analisis Sistem Informasi Geografis (SIG), luas catchment area Situ Gintung adalah 112,542 ha dan luas tubuh air Situ Gintung sendiri adalah 21,407 ha. Menurut Kepala Balai Besar Wilayah Sungai Ciliwung Cisadane, Pitoyo Subandrio, saat pertama kali dibangun oleh Belanda, Situ Gintung memiliki luas sekitar 31 ha dengan kedalaman sekitar $10 \mathrm{~m}$, namun akibat pendangkalan luasan situ ini semakin berkurang hingga kini hanya tersisa sekitar 21,4 ha saja, dengan kedalaman air dalam situ diperkirakan tinggal sekitar $4 \mathrm{~m}$ saja, sehinga volume air yang ada dalam waduk adalah hanya sekitar 856.000 $\mathrm{m}^{3}$ saja $^{(2)}$.

\subsection{Kondisi Penggunaan Lahan dan Area Yang Terkena Musibah}

Tabel 1 berikut ini merupakan hasil analisis penggunaan lahan berdasarkan data Peta RBI digital skala 1:25.000 dari Bakosurtanal. Sebaran spasial penggunaan lahan dalam catchment area Situ Gintung dapat dilihat dalam Gambar 4. Dari Gambar 4 juga terlihat bahwa pada area yang terkena musibah yaitu Desa Poncol dan Desa Gintung, daerah permukiman adalah yang paling luas (5,3 ha), sementara sisanya adalah tegalan/ ladang (3,6 ha) dan kebun (2,0 ha).
Tabel 1. Pengunaan Lahan di catchment area Situ Gintung

\begin{tabular}{|l|r|r|}
\hline \multirow{2}{*}{ Penggunaan Lahan } & \multicolumn{2}{|c|}{ Luas } \\
\cline { 2 - 3 } & (Ha) & \multicolumn{1}{c|}{ (\%) } \\
\hline Pemukiman & 51.4 & 45.6 \\
\hline Tegalan / Ladang & 18.0 & 16.0 \\
\hline Tubuh air & 19.0 & 16.9 \\
\hline Kebun / Perkebunan & 20.0 & 17.8 \\
\hline Rumput / Tanah kosong & 3.9 & 3.4 \\
\hline Gedung & 0.2 & 0.2 \\
\hline Total & $\mathbf{1 1 2 . 5}$ & $\mathbf{1 0 0 . 0}$ \\
\hline
\end{tabular}

Sumber : hasil analisis GIS

\section{ANALISIS HIDROLOGI}

\subsection{Kondisi Curah Hujan}

Ada banyak versi yang menyebutkan intensitas hujan yang terjadi pada tanggal 26 Maret 2009, atau sehari/semalam sebelum kejadian jebolnya tanggul di pagi harinya. Stasiun Meteorologi Ciputat yang merupakan stasiun terdekat dengan lokasi kejadian mencatat curah hujan pada tanggal 26 Maret 2009 sebesar 113,2 $\mathrm{mm} /$ hari, sementara dari Stasiun Meteorologi Pondok Betung curah hujan normal selama 3 jam disusul dengan curah hujan ekstrem $70 \mathrm{~mm}$ selama 1,5 jam ${ }^{(1)}$. Ditambahkan oleh Deputi Bidang Sistem Data dan Informasi Badan Meteorologi dan Geofisika (BMG) Prih Harjadi, curah hujan terdekat lainnya dari Stasiun Ciputat tercatat di Stasiun Lebak Bulus dengan intensitas hujan per hari sebesar 83 milimeter ${ }^{(3)}$. 


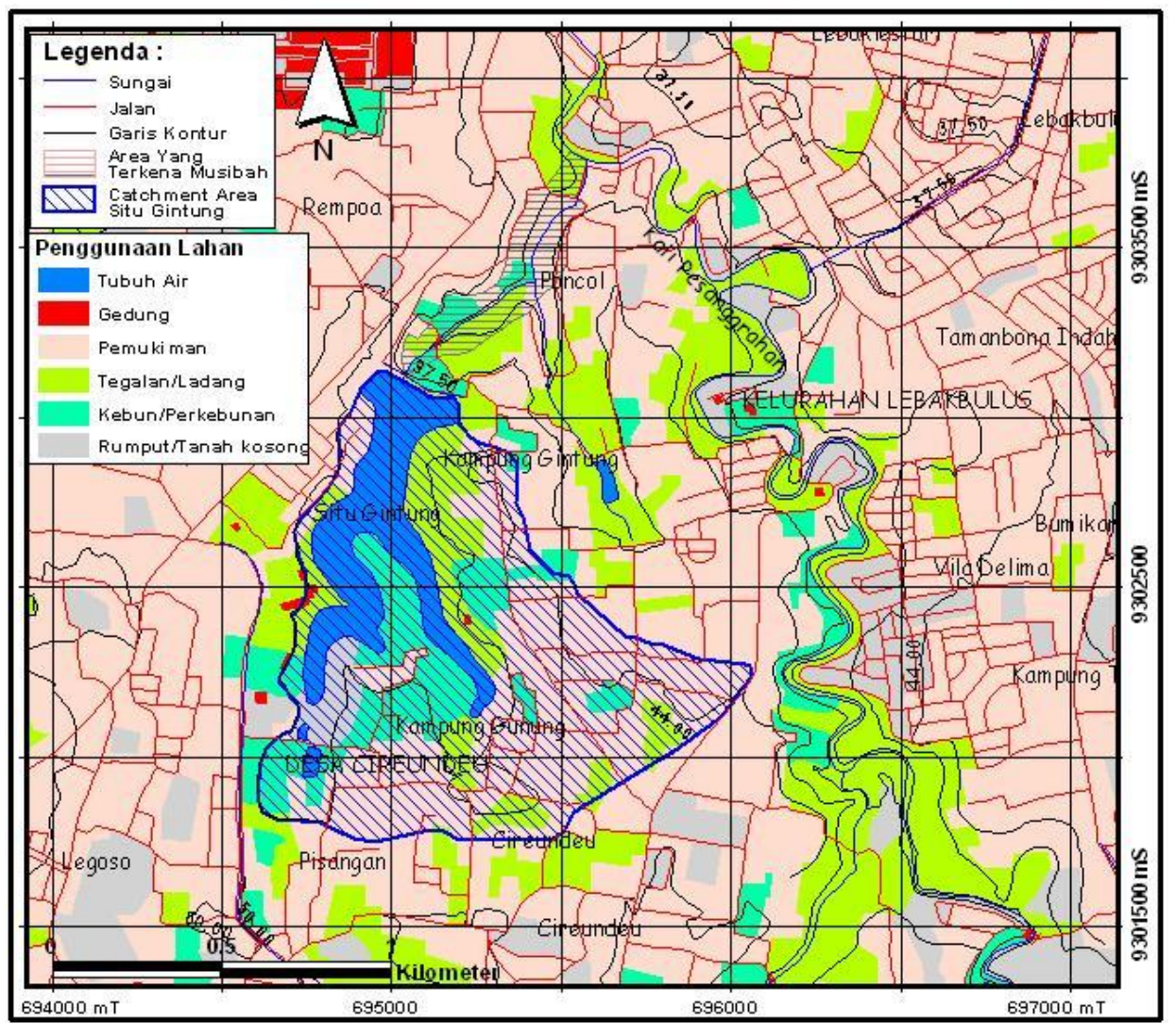

Gambar 4. Peta penggunaan lahan daerah Situ Gintung dan sekitarnya

(sumber : Peta RBI digital Bakosurtanal skala 1:25.000)

Sumber lain menurut Fadli Syamsudin yang melakukan analisis cuaca menggunakan citra satelit GMS MTSAT pada tanggal 26 dan 27 Maret 2009 dan radar cuaca program HARIMAU (Hydrometeorological ARray for Intraseasonal Monsoon AUtomonitoring) Badan Pengkajian dan Penerapan Teknologi (BPPT) yang berlokasi di Puspiptek, Serpong, menyebutkan bahwa terjadi dua tahapan fase curah hujan tinggi cenderung ekstrem 80-100 milimeter per jam pada 26 Maret pukul 13.00-14.30 (1,5 jam) dengan luasan 15 km x $15 \mathrm{~km}$ dan pukul 16.00-pukul 19.30 (3,5 jam) dengan luasan $25 \mathrm{~km} \times 25 \mathrm{~km}$ di wilayah Situ Gintung dan sekitarnya $a^{(4)}$.

Sebagai data pendukung tambahan, Penulis juga mempunyai data curah hujan untuk beberapa tahun periode ulang di Stasiun Ciputat berdasarkan Laporan Kegiatan Project Cisadane River Basin Development Feasibility Study tahun $1987^{(5)}$, yang dibuat oleh Departemen Pekerjaan Umum bekerjasama dengan Lavalin Int. Inc., Nippon Koei Co.Ltd. seperti yang tersaji dalam Tabel 2 berikut :

Tabel 2. Berbagai Periode Ulang Curah Hujan di Stasiun Ciputat.

\begin{tabular}{|c|c|c|c|c|c|c|}
\hline \multirow{2}{*}{ Tahun } & \multicolumn{7}{|c|}{ Periode Ulang } \\
\cline { 2 - 7 } & $\mathbf{2}$ & $\mathbf{5}$ & $\mathbf{1 0}$ & $\mathbf{2 0}$ & $\mathbf{5 0}$ & $\mathbf{1 0 0}$ \\
\hline $\mathbf{m m} /$ hari & 88 & 120 & 141 & 161 & 187 & 206 \\
\hline
\end{tabular}

Sumber: Departemen Pekerjaan Umum, Republik Indonesia, 1987

Jika mengacu pada data periode ulang untuk Stasiun Ciputat, sebetulnya curah hujan yang terjadi pada tanggal 26 Maret 2009 (113,2 $\mathrm{mm} /$ hari) masih tergolong rendah, dan terjadi untuk periode ulang yang pendek (sekitar 5 tahunan). Ini berarti curah hujan yang terjadi pada tanggal 26 Maret 2009 bukan merupakan curah hujan yang ekstrim karena ternyata berdasarkan Tabel 2, nilai curah hujan sebesar $113,2 \mathrm{~mm} /$ hari hanya merupakan nilai dari suatu periode ulang yang pendek. 


\subsection{Waktu Konsentrasi (Tc)}

Waktu konsentrasi (disimbolkan Tc) adalah waktu perjalanan yang diperlukan oleh air dari tempat yang paling jauh (hulu DAS) sampai ke titik pengamatan aliran air (outlet). Hal ini terjadi ketika tanah sepanjang kedua titik tersebut telah jenuh dan semua cekungan bumi lainnya telah terisi oleh air hujan. Diasumsikan bahwa bila lama waktu hujan sama dengan Tc berarti seluruh bagian DAS tersebut telah ikut berperan untuk terjadinya aliran air (debit) yang sampai ke titik pengamatan. Salah satu teknik untuk menghitung Tc yang paling umum adalah persamaan matematik yang dikembangkan oleh Kiprich (1940) sebagai berikut :

$$
\text { Tc }=0,0195 L^{0,77} \mathrm{~S}^{-0,385}
$$

\section{Dimana :}

$\mathrm{T}_{\mathrm{c}}=$ Waktu konsentrasi (menit)

$\mathrm{L}=$ Panjang maksimum aliran (meter)

$S=$ Beda ketinggian antara titik pengamatan dengan lokasi terjauh pada DAS dibagi panjang maksimum aliran.
Untuk mempermudah perhitungan Tc, Gambar 5 berikut ini memperlihatkan profil melintang dari catchment area Situ Gintung yang diambil antara titik outlet (titik jebolnya tanggul) dengan titik pada bagian hulu catchment area. Beda jarak horizontal antara kedua titik tersebut sekitar $1,4 \mathrm{~km}$ sedangkan beda jarak vertikalnya sekitar 5,6 m.

Berdasarkan data yang dapat diambil dari profil melintang pada Gambar 5, panjang maksimum aliran (L) dianggap mempunyai nilai $1,4 \mathrm{~km}=1.400 \mathrm{~m}$; dan beda tinggi antara titik pengamatan dengan lokasi terjauh pada bagian hulu DAS (S) adalah 5,6 m, maka nilai $\mathrm{S}$ adalah $5,6 \mathrm{~m} / 1.400 \mathrm{~m}=0,004$.

Berdasarkan nilai $L$ dan $S$ dari hasil perhitungan di atas, maka lamanya waktu konsentrasi berdasarkan Persamaan 1 adalah sebagai berikut :

$$
\begin{aligned}
\text { TC } & =\mathbf{0 , 0 1 9 5} \mathbf{L}^{0,77} \mathbf{S}^{-0,385} \\
& =0,0195(1.400)^{0,77}(5,6 / 1.400)^{-0,385} \\
& =0,0195\left(1.4000^{0,77}(0,004)^{-0,385}\right. \\
& =\mathbf{4 3 , 2 2 7 5} \text { menit } \\
& =\mathbf{0 , 7 2} \text { jam }
\end{aligned}
$$

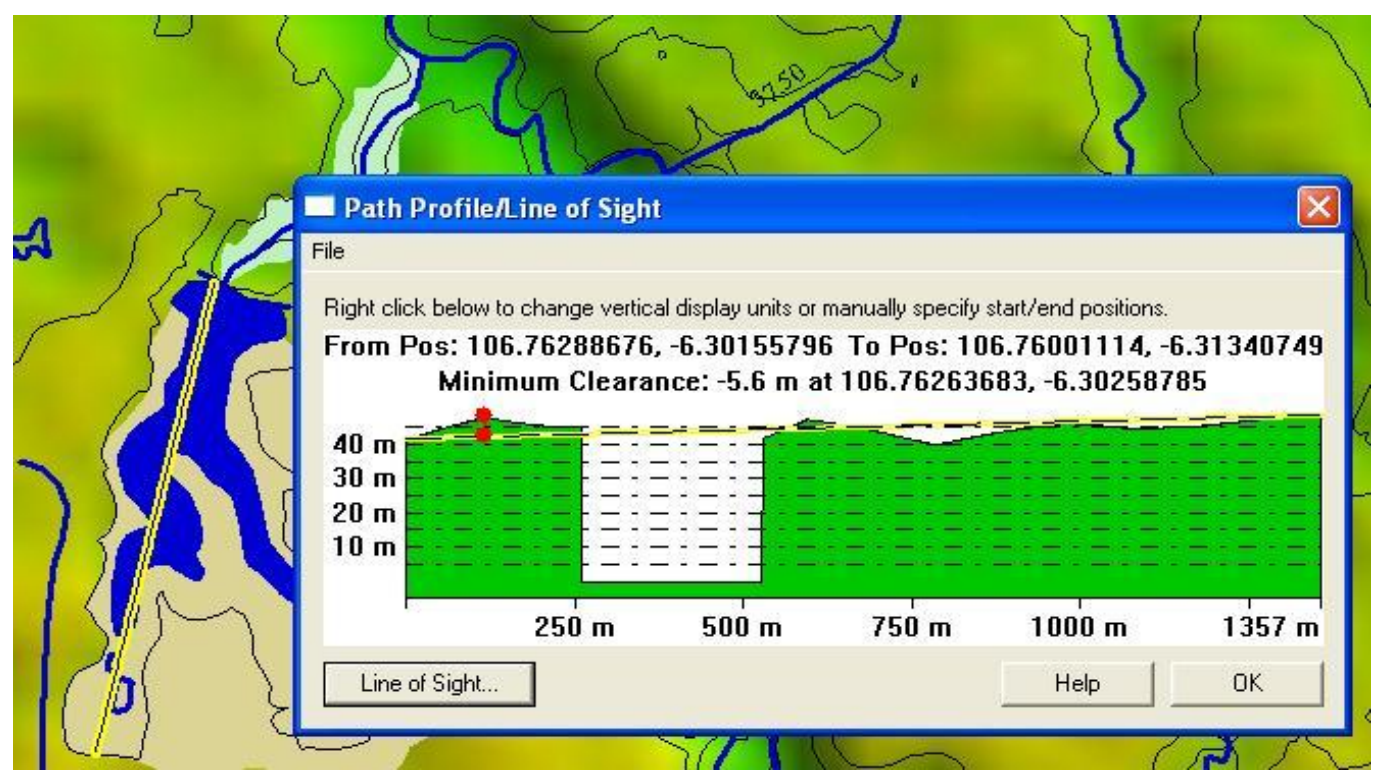

Gambar 5. Profil melintang catchment area Situ Gintung.

\subsection{Koefisien Aliran (C)}

Perhitungan koefisien aliran dilakukan dengan tabulasi untuk setiap jenis penggunaan lahan. Faktor luasan tiap jenis penggunaan lahan dijadikan sebagai faktor pembobot (weighing factors). Rumus yang digunakan adalah sebagai berikut :

$$
C=\frac{C 1 . a 1+C 2 \cdot a 2+C 3 \cdot a 3+\ldots . . .+C n . a n}{A}
$$

Keterangan:

$$
\begin{aligned}
& C=\text { Koefisien seluruh DAS } \\
& C 1=\text { Koefisien Aliran Tabel menurut } \\
& \text { penggunaan lahan } 1 \text { sampai } n \\
& a=\text { Luas masing-masing penggunaan } \\
& \text { lahan dari } 1 \text { sampai } n \\
& A=\text { Luas total penggunaan lahan }
\end{aligned}
$$


Tabel 3 : Perhitungan Koefisien Aliran (C).

\begin{tabular}{|c|c|c|c|c|}
\hline Penggunaan Lahan & $\begin{array}{c}\text { Luas (Ha) } \\
\sim 1 \sim\end{array}$ & $\begin{array}{l}\text { (\%) Luas } \\
\sim 2 \sim\end{array}$ & $\begin{array}{l}\mathbf{C} \\
\sim 3 \sim\end{array}$ & $\begin{array}{l}\text { C tertimbang } \\
\sim\left(2^{*} 3\right) / 100 \sim\end{array}$ \\
\hline Pemukiman & 51.4 & 45.6 & 0,60 & 0.2736 \\
\hline Tegalan & 18.0 & 16.0 & 0,50 & 0.0800 \\
\hline Badan air & 19.0 & 16.9 & 0,90 & 0.1521 \\
\hline Kebun & 20.0 & 17.8 & 0,40 & 0.0712 \\
\hline Rumput/tanah kosong & 3.9 & 3.4 & 0,50 & 0.0170 \\
\hline Gedung & 0.2 & 0.2 & 0,70 & 0.0014 \\
\hline Total & 112.5 & 100.0 & & 0.5953 \\
\hline
\end{tabular}

Sumber : hasil perhitungan

\subsection{Perhitungan Debit Puncak ( $\left.Q_{\text {maks }}\right)$ Dengan Metode Rasional}

Perhitungan debit puncak ( $Q_{\text {maks }}$ ) dilakukan dengan menggunakan rumus metode rasional. Adapun rumus untuk metode rasional adalah sebagai berikut :

$$
Q p=0,0028 \text { C.i.A ..... (P.3) }
$$

Keterangan:

$$
\begin{aligned}
& \mathrm{Qp}=\text { Debit Puncak }\left(\mathrm{m}^{3} / \mathrm{dt}\right) \\
& \mathrm{I}=\text { Intensitas Hujan }(\mathrm{mm} / \mathrm{jam}) \\
& \mathrm{C}=\text { Koefisien Aliran } \\
& \mathrm{A}=\text { Luas DAS (ha) }
\end{aligned}
$$

Metoda rasional menyatakan bahwa puncak limpasan pada suatu DAS akan diperoleh pada intensitas hujan maksimum (i) yang lamanya sama dengan waktu konsentrasi (Tc) (6). Apabila lama hujannya kurang dari waktu konsentrasi, maka intensitasnya kemungkinan lebih besar akan tetapi luas DAS yang memberikan kontribusi terhadap debit akan lebih kecil dari total luas DAS (A). Apabila lama waktu hujan lebih besar dari waktu konsentrasi maka luas areal sama dengan total luas DAS (A) tetapi intensitasnya kurang dari intensitas hujan pada lama hujan sama dengan Tc.

Yang perlu dicermati dari keterangan pada paragraf di atas adalah dalam penggunaan metode rasional disyaratkan bahwa besarnya harus sama dengan Tc. Berdasarkan beberapa data curah hujan pada pembahasan sub bab 3.1. terdahulu, tidak ada nilai intensitas hujan yang lamanya sama dengan nilai Tc dari hasil perhitungan pada sub bab 3.2. $(43,2275$ menit atau 0,72 jam).

Dari beberapa nilai intensitas hujan yang ada, yang paling mendekati adalah 80-100 $\mathrm{mm} / \mathrm{jam}$ (sumber : Fadli Syamsudin ${ }^{(4)}$ ). Namun nilai ini pun dianggap masih belum sama dengan waktu konsentrasinya, sehingga perlu disamakan terlebih dahulu. Dengan asumsi bahwa kejadian hujan seragam/konstan selama 1 jam, maka nilai intensitas hujan untuk Tc selama 43,2275 menit atau 0,72 jam adalah :

$$
\begin{aligned}
\mathrm{i}_{0,72} & =[80+\{0,5 \times(100-80)\} \times(43,2275 / 60) \\
& =64,84 \mathrm{~mm} / \mathrm{jam}
\end{aligned}
$$

Sedikit catatan, sebetulnya metode yang paling tepat untuk menentukan besarnya intensitas hujan dengan waktu yang kurang dari 1 jam (hitungan menit tertentu) adalah dengan menggunakan kurva Intensity Duration Curve (IDF). Namun karena sulitnya memperoleh data curah hujan yang untuk periode jam-jaman, maka kurva IDF ini masih menjadi sesuatu yang langka dan sulit dibuat di Indonesia.

Dengan menggunakan data yang ada, besarnya intensitas hujan $\left(\mathrm{i}_{0}, 72\right)$ sebesar 64,84 $\mathrm{mm} / \mathrm{jam}$; koefisien aliran (C) berdasarkan perhitungan pada Tabel 3 sebesar 0,5805; dan luas catchment area (A) menurut Tabel 1 seluas 112,5 ha, maka besarnya debit puncak (Qmaks) berdasarkan Persamaan 3 adalah sebagai berikut :

\section{$\mathrm{Qp}=0,0028 \times 0,5953 \times 64,84 \mathrm{~mm} / \mathrm{jam} \times 112,5 \mathrm{ha}$ $=12,16 \mathrm{~m}^{3} / \mathrm{dt}$.}

\subsection{Penambahan Volume Air dan Kenaikan Muka Air}

Perhitungan terhadap jumlah air yang masuk selama hujan dilakukan dengan cara menghitung tebal hujan dikalikan luas catchment area dimana tebal hujan dalam sehari menggunakan data curah hujan dari Stasiun Meteorologi Ciputat yaitu sebesar 113,2 mm dan luas 112,5 ha, (dalam perhitungan ini pengaruh evapotranspirasi diabaikan dan seluruh air hujan yang jatuh dalam catchment area Situ Gintung diasumsikan masuk ke dalam tubuh air, baik yang jatuh langsung di atas tubuh air maupun yang jatuh di bagian daratan) maka :

$$
\begin{aligned}
& \text { Volume }=\text { Tebal hujan } \times \text { Luas DAS } \\
& =(113,2 \mathrm{~mm} / 1000) \times(112,5 \times 10.000) \\
& =127.350 \mathrm{~m}^{3}
\end{aligned}
$$

Berdasarkan tinjauan hidrologi dapat dijelaskan bahwa telah terjadi peningkatan debit 
puncak mencapai 18,286 $\mathrm{m}^{3} / \mathrm{dt}$ dengan tambahan volume air sebesar $127.350 \mathrm{~m}^{3}$, yang dipicu oleh hujan setebal 113,2 $\mathrm{mm}$ dalam sehari.

Dari hasil perhitungan volume air yang masuk ke Situ Gintung di atas, maka dengan penambahan volume air sebesar $127.350 \mathrm{~m}^{3}$ dan asumsi luasan situ seluas 16,2 ha, maka terjadi kenaikan muka air setinggi $127.350 \mathrm{~m}^{3} / 16,2$ ha $=78,61 \mathrm{~cm}$.

\section{PEMBAHASAN}

Jika mengacu pada keterangan dari Fadli Syamsudin(4) yang menyatakan bahwa di sekitar lokasi kejadian terjadi hujan dengan intensitas tinggi mulai siang hari (tanggal 26 Maret 2009) pukul 13.00 sampai dengan malam hari pukul 19.30 (ada jeda waktu 1,5 jam dari pukul 14.30 sampai dengan pukul 19.30), sementara berdasarkan perhitungan waktu konsentrasi untuk catchment area Situ Gintung yang hanya memerlukan waktu sekitar 43,22 menit atau 0,72 jam, hal ini membuktikan bahwa faktor curah hujan bukan merupakan faktor utama penyebab jebolnya tanggul. Mengapa demikian, karena peristiwa jebolnya tanggul terjadi pada sekitar pukul 05.30 tanggal 27 Maret 2009, atau ada waktu sekitar 10 jam dan ini sudah jauh melebihi waktu konsentrasi yang terjadi. Hal ini juga diperkuat dengan keterangan Sutopo Purwo Nugroho(1) yang menyatakan bahwa di daerah tersebut pernah terjadi hujan dengan intensitas yang jauh lebih tinggi daripada kejadian hujan tanggal 26 Maret 2009, yaitu pada tahun 1996 (180 mm/hari) dan tahun 2007 (275 - 300 $\mathrm{mm} /$ hari), dimana pada kedua kejadian hujan tersebut kondisi Jakarta banjir besar, sementara kondisi tanggul Situ Gintung sendiri tetap aman.

Lantas pertanyaannya, apa sebenarnya yang menjadi faktor utama penyebab terjadinya jebolnya tanggul Situ Gintung tersebut? Penulis berpendapat bahwa kondisi tanggul yang memang sudah rusak / mengalami kebocoran sebelumnya itulah yang merupakan penyebab utama musibah yang telah menelan cukup banyak korban tersebut. Berdasarkan informasi melalui beberapa surat kabar maupun melalui media televisi, masyarakat sekitar memang sudah mengetahui terjadinya kebocoran pada tanggul situ beberapa minggu sebelum kejadian dan hal ini sebetulnya sudah dilaporkan kepada pemerintah melalui aparat desa setempat, namun sayangnya hal ini tidak segera mendapat respon serius. Bagaimanapun juga, suatu bangunan reservoir baik waduk ataupun situ dibangun dengan desain untuk umur ekonomis (life time) tertentu yang tergantung dengan tingkat resiko yang diambil berdasarkan periode ulang yang dipilih. Jika melihat pada sejarahnya yang didesain untuk sarana irigasi, kemungkinan
Pemerintah Belanda dahulu membangun situ ini tidak untuk desain umur ratusan tahun. Berubahnya fungsi lahan dari lahan pertanian menjadi areal permukiman padat yang kemudian terjadi saat ini merupakan kesalahan besar, dan ini tidak dipertimbangkan oleh Pemerintah Belanda pada saat mendesain pembangunan situ ini. Jadi karena memang umur tanggul yang sudah dalam 'kondisi lelah' inilah yang menyebabkan tanggul tersebut jebol. Kondisi serupa seperti ini diyakini oleh penulis hampir terjadi untuk seluruh situ di sekitar Jabodetabek buatan Pemerintah Belanda dulu yang saat ini masih ada, sehingga semestinya pemerintah perlu memperhatikan hal tersebut berdasarkan pelajaran dari musibah yang telah menimpa Situ Gintung.

Jika melihat pada besarnya debit puncak berdasarkan hasil perhitungan yang sebesar $12,16 \mathrm{~m}^{3} /$ detik, maka nilai tersebut sebenarnya masih belum terlalu melebihi kapasitas spillway yang menurut keterangan Dirjen Sumber Daya Air Departemen Pekerjaan Umum, Iwan Nusyirwan Diar mampu mengalirkan 12 $\mathrm{m}^{3} /$ detik $^{(7)}$. Sayangnya dalam penelitian ini penulis tidak mendapatkan data berapa tinggi muka air (TMA) Situ Gintung pada saat sebelum kejadian dan berapa ketinggian elevasi bangunan spillway yang ada, sehingga dengan diperolehnya perhitungan tambahan volume air dan kenaikan TMA pada sub bab 3.5. tidak dapat diketahui apakah saat kejadian volume air situ melimpas atau tidak. Namun, sekalipun diasumsikan pada saat itu terjadi limpasan maka seharusnya hal tersebut tidak menjadi masalah karena berdasarkan hasil perhitungan debit puncak masih mampu berada di bawah kapasitas debit spillway seperti dijelaskan di atas. Yang pasti, akibat adanya penambahan volume air sebanyak $127.350 \mathrm{~m}^{3}$ dan kenaikan TMA setinggi $78,61 \mathrm{~cm}$ telah menyebabkan tekanan hidrostatik air terhadap tanggul meningkat, apalagi di bagian outlet.

Berdasarkan hasil pengamatan lapangan penulis di lokasi kejadian, pada bagian outlet Situ Gintung pada saat sebelum kejadian hanya tinggal satu saluran pembuangan yang masih ada, yaitu di titik dimana jebolnya tanggul tersebut. Dari keterangan Kepala Balai Besar Wilayah Sungai Ciliwung Cisadane, Pitoyo Subandrio(2), saluran pembuangan yang awalnya dibangun oleh Pemerintah Belanda dulu selebar 5 - 7 meter, saat ini saluran tersebut hanya tinggal selebar 1 meter saja. Mengapit saluran pembuangan utama yang menjadi titik dimana tanggul jebol, pada sisi sudut timur maupun barat bagian outlet juga terdapat pintu air sebagai saluran pembuangan sekunder. Lebar saluran saat ini hanya tinggal $30 \mathrm{~cm}$ saja, dan penulis juga meyakini bahwa sama halnya dengan 
kondisi saluran primer, kedua saluran sekunder tersebut pada awalnya jauh lebih lebar daripada kondisi sekarang.

Kombinasi dari berbagai permasalahan di atas; umur bangunan tanggul Situ Gintung yang sudah dalam 'kondisi lelah' dan kondisi sekarang yang sudah tidak sesuai dengan kondisi pada saat awal dibangun oleh Pemerintah Belanda inilah yang dinilai sebagai faktor utama penyebab tragedi pada tanggal 27 Maret 2009 yang lalu. Memang benar faktor curah hujan saat itu juga sebagai faktor penyebab, tapi bukan sebagai faktor utama. Jika seandainya tidak terkondisi sebagaimana yang sudah dipaparkan di atas, maka hujan yang terjadi sesaat sebelum tragedi tersebut tidak akan membawa malapetaka yang sangat merugikan tersebut.

Jika melihat pada Gambar 2, 3 dan 5 yang memperlihatkan kondisi topografi berdasarkan DEM dan profil 3 dimensi dari catchment area Situ Gintung, titik dimana lokasi jebolnya tanggul memang merupakan titik dimana lokasi tanggul paling memiliki perbedaan elevasi tertinggi (sekitar 20 meter) dengan daerah di luar catchment area, dan parahnya lagi, lokasi tersebut merupakan areal permukiman padat. Dengan demikian dapat dibayangkan bagaimana dahsyatnya air yang mengalir saat tanggul tersebut jebol dan menimpa daerah permukiman yang ada di bawahnya. Air bah yang terjadi pada peristiwa ini jauh lebih dahsyat dibandingkan dengan musibah tsunami di Aceh, jika dilihat dari ketinggian air yang jatuh menimpa areal permukiman penduduk tersebut.

Dari peristiwa jebolnya tanggul Situ Gintung ini, penulis menyarankan agar pemerintah pusat melalui instansi yang terkait segera melakukan evaluasi dan inspeksi terhadap beberapa situ yang ada di sekitar wilayah Jabodetabek, karena sangat diyakini hampir semua situ yang masih ada sekarang memiliki kondisi yang sama dengan Situ Gintung karena dibangun hampir pada masa yang bersamaan dengan Situ Gintung oleh Pemerintah Belanda dahulu. Peristiwa ini juga sekaligus memberikan pelajaran bahwa sebenarnya Tata Ruang Wilayah yang saat ini sudah banyak dilanggar dan tidak sesuai lagi dengan peruntukkannya (sebagai contoh, beberapa situ diurug untuk dijadikan areal permukiman atau mall; atau dari kasus Situ Gintung sendiri dimana areal permukiman padat yang menjadi areal musibah sebenarnya dahulu merupakan areal pertanian) dapat memberikan kerugian besar yang dapat menelan banyak korban maupun kerugian baik secara materil. Sebagai penutup tulisan ini, penulis berharap semoga pelajaran dari tragedi Situ Gintung ini mendapat perhatian serius dari Pemerintah selaku penentu kebijakan dalam kaitannya dengan tindakan konservasi yang sangat diperlukan untuk menyelamatkan kota Jakarta khususnya, yang pada kondisi sekarang ini sudah memiliki permasalahan degradasi lingkungan yang sangat kompleks.

\section{KESIMPULAN}

Dari hasil analisis yang telah dilakukan, maka dapat ditarik beberapa kesimpulan sebagai berikut :

- Faktor curah hujan juga turut mempengaruhi penyebab jebolnya tanggul Situ Gintung, namun bukan sebagai faktor utama. Ada beberapa alasan yang mendasari kesimpulan ini, yaitu :

a. Peristiwa jebolnya tanggul terjadi pada selang waktu sekitar 10 jam setelah hujan dengan intensitas tinggi berlangsung, sementara waktu konsentrasi untuk catchment area Situ Gintung hanya memerlukan waktu relatif singkat, yaitu sekitar 43 menit saja.

b. Hujan dengan intensitas yang lebih besar dibandingkan curah hujan pada tanggal 26 Maret 2009 (113,2 mm/hari) pernah terjadi di daerah tersebut, yaitu pada tahun 1996 (180 mm/hari) dan tahun 2007 (275 - $300 \mathrm{~mm} /$ hari), dimana pada kedua kejadian hujan tersebut kondisi Jakarta banjir besar, sementara kondisi tanggul Situ Gintung sendiri tetap aman.

c. Berdasarkan perhitungan periode ulang kejadian hujan di daerah Ciputat, curah hujan setebal 113,2 $\mathrm{mm} / \mathrm{hari}$ dapat terjadi untuk periode ulang 5 tahun. Hal ini berarti bahwa curah hujan dengan kondisi seperti pada tanggal 26 Maret 2009 tersebut dapat terjadi sebanyak 15 kali semenjak pertama kalinya dibangun (tahun 1932-1933) hingga tahun 2009, dan ini dapat dianggap tidak beresiko menimbulkan bahaya dengan peluang frekuensi terjadinya yang cukup sering tersebut.

- Faktor utama penyebab jebolnya tanggul Situ Gintung adalah karena usia bangunan tanggul yang sudah tua yang semakin diperparah dengan kondisi saluran pembuangan yang sudah tidak berfungsi sebagaimana pada saat awal dibangun oleh Pemerintah Belanda dulu.

- Lebar saluran pembuangan yang jauh berkurang dan semakin menyempit dibandingkan dengan kondisi awal saat dibangun oleh Pemerintah Belanda dulu, menyebabkan beban tanggul semakin berat karena tekanan hidrostatik air di dalam Situ semakin besar. 


\section{DAFTAR PUSTAKA}

1. Brigitta Isworo Laksmi. 2009. Tanggul, Pemicu dan Audit Teknologi. Artikel dalam Harian Kompas, 1 April 2009, Jakarta.

2. Mulyawan Karim. 2009. Setelah 76 Tahun, Tanggul Buatan Belanda Itu Pun Jebol. Artikel dalam Harian Kompas, 28 Maret 2009, Jakarta.

3. Fahmi Firdaus. 2009. BMG: Situ Gintung Jebol Dipicu Cuaca Ekstrim. Situs www.okezone.com , 31 Maret 2009

4. Fadli Syamsudin. 2009. Faktor Cuaca Pada Bencana Situ Gintung. Artikel dalam Harian Kompas, 1 April 2009, Jakarta.

5. Departemen Pekerjaan Umum bekerjasama dengan Lavalin Int. Inc., Nippon Koei Co.Ltd. 1987. Laporan Kegiatan Project Cisadane River Basin Development Fisibility Study tahun 1987, Departemen Pekerjaan Umum Republik Indonesia. Jakarta.

6. Dedi Kusnadi Kalsim. 2009. Pendugaan Puncak Limpasan. Laboratorium Teknik Tanah dan Air, FATETA Institut Pertanian Bogor. Bogor.

7. Antara News. 2009. Pemerintah Yakin Secara Struktur Situ Gintung Kuat. Situs www.antara.co.id, 1 April 2009. 